\title{
Functional food properties of non-digestible oligosaccharides: a consensus report from the ENDO project (DGXII AIRII-CT94-1095)
}

\author{
Jan Van Loo ${ }^{1}$, John Cummings ${ }^{2}$, Nathalie Delzenne ${ }^{3}$, Hans Englyst ${ }^{2}$, Anne Franck ${ }^{1}$, Mark Hopkins ${ }^{2}$, \\ Nadine Kok ${ }^{3}$, George Macfarlane ${ }^{2}$, Dorothy Newton ${ }^{2}$, Michael Quigley ${ }^{2}$, Marcel Roberfroid ${ }^{3}$, \\ Trinette van Vliet ${ }^{4}$ and Ellen van den Heuvel $^{4}$ \\ ${ }^{1}$ ORAFTI, Aandorenstraat 1, B3300 Tienen, Belgium \\ ${ }^{2}$ Dunn Clinical Nutrition Centre, Hills Rd, Cambridge CB2 2DH, UK \\ ${ }^{3}$ Catholic University Louvain, Brussels, Belgium \\ ${ }^{4}$ TNO, Zeist, The Netherlands
}

(Received 26 June 1998 - Revised 11 September 1998 - Accepted 14 September 1998)

\begin{abstract}
This paper results from the final phase of the ENDO project (DGXII AIRII-CT94-1095), a European Commission-funded project on non-digestible oligosaccharides (NDO). All participants in the programme met to perform a consensus exercise on the possible functional food properties of NDO. Topics studied during the project (including a workshop on probiotics and prebiotics) and related aspects, for which considerable evidence has been generated recently, were evaluated on the basis of existing published scientific evidence. There was a general consensus that: (1) there is strong evidence for a prebiotic effect of NDO in human subjects. A prebiotic effect was defined as a food-induced increase in numbers and/or activity predominantly of bifidobacteria and lactic acid bacteria in the human large intestine; (2) there is strong evidence for the impact that NDO have on bowel habit; (3) there is promising evidence that consumption of inulin-type fructans may result in increased Ca absorption in man; (4) there are preliminary indications that inulin-type fructans interact with the functioning of lipid metabolism; (5) there is preliminary evidence in experimental animals of a preventive effect against colon cancer. Human nutrition studies are needed to substantiate these findings. It was concluded that the nutritional properties of NDO may prove to be a key issue in nutritional research in the future.
\end{abstract}

Functional foods: Non-digestible oligosaccharides: Prebiotics

Dietary carbohydrates represent a complex group of food components which, besides their usefulness for food technologists, have a variety of physiological and nutritional properties in man. According to the scientists who participated in the discussion, it has become clear over the last decade that the group of non-digestible oligosaccharides (NDO) play, or are likely to play, an important nutritional role (Cummings et al. 1997). As is shown in Table 1, NDO are composed of a variety of monosaccharides that are linked in several ways (type of bond and chain length) and typically are composed of a polydisperse set of comparable molecules differing only in chain length. The available NDO preparations are either (1) extracted from natural sources (e.g. inulin, soyabean oligosaccharides) followed by partial enzymic hydrolysis (e.g. xylo-oligosaccharides, oligofructose, malto-oligosaccharides), or (2) synthesized by subjecting disaccharides such as lactose or sucrose to the action of transferases (e.g. transgalacto-oligosaccharides).
NDO such as the fructans and oligosaccharides from beans have always been present naturally in human plant foods, although total daily intakes are largely unknown. In populations consuming a Western-style diet, the intake of inulin-type fructans has been estimated to range between 1 and $4 \mathrm{~g} / \mathrm{d}$ (Van Loo et al. 1995).

Although differing in their chemical characteristics, all the NDO resist digestion in the human small intestine and they are potential substrates for the bacteria that colonize the large intestine.

Here, we report the consensus reached by the authors, who collaborated for a period of more than 3 years in a shared-cost research programme funded by the European Commission (DGXII AIRII-CT94-1095) and known as the ENDO project (European project on non-digestible oligosaccharides). In reaching this consensus, the authors considered both the results of their own research in the ENDO project and the data available in the scientific literature. One 
Table 1. Non-digestible oligosaccharides (NDO) that were studied in the ENDO project*

\begin{tabular}{|c|c|c|c|c|c|}
\hline Name & $\begin{array}{l}\text { Type of bond and composition/ } \\
\text { Production method }\end{array}$ & DP & Digestibility† & $\begin{array}{l}\text { Allowed for human } \\
\text { consumption in: }\end{array}$ & $\begin{array}{c}\text { RSCC } \ddagger \\
(\mathrm{g} / \mathrm{kg})\end{array}$ \\
\hline $\begin{array}{l}\text { Xylo-oligosaccharides } \\
\text { (350 or } 700 \mathrm{~g} \text { OS } / \mathrm{kg} \text { ) }\end{array}$ & $\begin{array}{l}\beta(1 \rightarrow 4) \text {-Linked xylose moieties/ } \\
\text { Enzymic hydrolysis of xylan }\end{array}$ & $2-4$ & --- & Japan & 294 \\
\hline $\begin{array}{l}\text { Transgalactosylated } \\
\text { oligosaccharides } \\
\text { (550 or } 850 \mathrm{~g} \mathrm{OS} / \mathrm{kg} \text { ) }\end{array}$ & $\begin{array}{l}\text { 6' Galactosyllactose (with Aspergillus } \\
\text { oryzae } \beta \text {-galactosidase); } \beta(1 \rightarrow 4) \\
\text { 4' Galactosyllactose (with } \\
\text { Cryptococcus laurentii } \beta \text { - } \\
\text { galactosidase); } \beta(1 \rightarrow 6) / \\
\text { Transgalactosylation of lactose }\end{array}$ & $2-8$, mostly 3 & --- & $\begin{array}{l}\text { Japan, some EC } \\
\text { countries }\end{array}$ & NM \\
\hline $\begin{array}{l}\text { Palatinose } \\
\text { condensates } \\
(950 \mathrm{~g} \mathrm{OS} / \mathrm{kg})\end{array}$ & $\begin{array}{l}\text { Enzymically rearranged sucrose } \\
\text { molecules (Palatinit) subsequently } \\
\text { pyrolysed. Various types of bonds }\end{array}$ & $2-7$ & -- to - & Japan & 463 \\
\hline Oligofructose & $\begin{array}{l}\beta(2 \rightarrow 1) \text { Fructans/ } \\
\text { Hydrolysis of chicory inulin or } \\
\text { transfructosylation from sucrose }\end{array}$ & $\begin{array}{l}2-8 \\
3-5\end{array}$ & --- & EC, USA, Japan & 874 \\
\hline Pyrodextrin & $\begin{array}{l}\text { Complex mixture/ } \\
\text { Pyrolysis of maize or potato starch }\end{array}$ & $\begin{array}{l}\text { Complex } \\
\text { mixture }\end{array}$ & -- & Japan & 200 \\
\hline
\end{tabular}

F, Fructose; G, Glucose; Gal, Galactose; DP, degree of polymerization; RSCC, resistant short-chain carbohydrates; OS, oligosaccharides; EC, European Community; NM, not measured.

* The criteria taken into consideration for human feeding studies were the commercial availability and the approval for human consumption in at least one country. Some promising NDO are also shown for comparative in vitro research.

$\dagger(---),>90 \%$ arrives in the colon; $(--)$, between 50 and $90 \%$ arrives in the colon; (-), about $50 \%$ arrives in the colon; (+), digestible.

$\ddagger$ As analysed by the method of M Quigley and $\mathrm{H}$ Englyst (unpublished) developed as part of the ENDO project. Values are means of three analyses.

of the objectives of the ENDO project was to contribute toward answering the question: are NDO functional food ingredients? Although not yet completely agreed on by the scientific community, the concept of functional foods refers to: 'foods similar in appearance to conventional foods that are consumed as part of a normal diet and have demonstrated physiological benefits and/or reduce the risk of chronic disease beyond basic nutritional functions' (Clydesdale, 1997).

This consensus report aims to evaluate current scientific knowledge on the nutritional properties of NDO in light of the emerging concept of functional food science. The evidence was categorized as strong (based on confirmed human feeding studies), promising (human feeding studies needing confirmation) or preliminary (experimental animal studies). In addition, this consensus report makes proposals for future research.

\section{Consensus report}

This consensus report is divided into five sections: (1) analytical aspects; (2) bowel habit and gut flora; (3) mineral absorption; (4) lipid metabolism; and (5) experimental effects in relation to colon cancer. In each section, the state of the art is summarized, with emphasis on the relevant publications, followed by a report on the new developments generated during the ENDO project and, finally, the consensus reached by the group on the particular issue.
During the preparation of this report (early 1998) more work was published on NDO. These data are included in the state-of-the-art sections.

\section{Definition, classification and analysis}

State of the art. In the International Union of Pure and Applied Chemistry - International Union of Biochemistry (IUPAC-IUB) nomenclature, an oligosaccharide is defined as being composed of two to about ten monomers linked together, but some of the NDO under discussion have a chain length greater than this. Although the NDO are very similar to true oligosaccharides from a physiological point of view, physiological variables cannot be used as the only criteria for classification. A practical working approach to distinguish NDO from other groups of carbohydrates is proposed. Analytical methods have been developed to identify, characterize and quantify NDO as pure chemicals, as mixtures and as components of complex food products. Methods are available for quantification of the inulin-type fructans (Quemener et al. 1994; Van Loo et al. 1995; Hoebregs, 1997).

ENDO contribution. It has been demonstrated that the NDO can be distinguished analytically from polysaccharides on the basis of their solubility in ethanol $(800 \mathrm{ml} / \mathrm{l})$, at $\mathrm{pH} 2$, at a temperature of $0^{\circ}$ for $30 \mathrm{~min}$. These conditions are pragmatic and easily reproducible. NDO (termed resistant short-chain carbohydrates by Englyst's 
group) remain in solution after the dispersal and hydrolysis of starch and the precipitation of NSP in the Englyst procedure for determination of NSP (Englyst et al. 1994).

As part of the present study, a GLC procedure was developed for the measurement of total NDO as the sum of their constituent sugars, which includes the option of specific determination of fructans. In the procedure, monoand disaccharides are measured directly and subtracted from the total carbohydrates in solution to give values for the NDO. In some studies, particularly fermentation measurements, it is important to be able to quantify individual NDO. High-performance anion exchange chromatography with pulsed amperometric detection was chosen for this purpose, as this technique allows separation of carbohydrates with a degree of polymerization from 2 to about 60 . A problem with this approach, however, has been the lack of commercially available standards for the purpose of determining response factors. Since response factors obtained with pulsed amperometric detection for carbohydrates with different degrees of polymerization are known to be very variable (Ammeraal et al. 1991), it is not possible to extrapolate response factors from known species to those of unknown chain length. As part of the ENDO project, M Quigley and H Englyst (unpublished results) have overcome this problem by development of a technique for first separating the NDO by high-performance anion exchange chromatography and then using a novel post-column acid hydrolysis technique to convert the NDO into their constituent monosaccharides, thereby allowing the use of readily available monosaccharide standards for quantification.

The non-digestibility of the NDO can be demonstrated in vitro by subjecting them to treatment with pancreatic and small-intestinal enzymes, and in vivo for human subjects with ileostomized volunteers. These are patients whose large bowel has been removed and who have a stoma at the end of the ileum. In such subjects, digestion is limited to the small intestine, and the remainder of the food bolus is available for collection into a pouch; this is considered to be representative of material that would enter the colon. Carbohydrates are termed indigestible when at least $90 \%$ of the quantity ingested is recovered in the pouch (Knudsen \& Hessov, 1995; Ellegård et al. 1996).

Very few NDO have been tested for digestibility in vivo, but for the inulin-type fructans the data from in vitro studies match those obtained in vivo. Table 1 shows the chemical structure, molecular size and sources of the NDO studied in this project. Analysis of these preparations indicates that whilst some are very pure, containing $86-87 \%$ NDO e.g. inulin and oligofructose, for others the NDO content is a minor fraction, about $20-30 \%$, the rest comprising free mono- and disaccharides, starch and even NSP. For example, the xylo-oligosaccharides studied contained $(\mathrm{g} / \mathrm{kg})$ : 294 NDO, 410 starch and 150 monosaccharides. This is an important factor to bear in mind when interpreting human or animal feeding studies.

Consensus. NDO can be distinguished from other carbohydrates on the basis of their solubility in vitro under specified conditions and their resistance to human intestinal enzymes. Methods for the quantitative analysis of NDO in general, and the inulin-type fructans in particular, are available.

\section{Effect on the colonic microflora}

NDO escape digestion in the human small bowel and are potential substrates for hydrolysis and fermentation by intestinal bacteria. Three major consequences of colonic fermentation have been studied: (1) the increase in bacterial biomass that leads to an increase in faecal output; (2) the production of short-chain fatty acids as some of the end-products of the fermentation process; (3) the prebiotic effect.

\section{Increase in biomass and stool bulking}

State of the art. NDO remain in solution in the chyme and contribute to the osmotic pressure, resulting in increased water flow. NDO are fermented by the colonic microflora, and this results in production of gases, short-chain fatty acids and lactate, which are known to affect gastrointestinal motility (Cherbut et al. 1994). The fermentation of NDO results in the production of biomass, theoretically at least $300 \mathrm{~g} / \mathrm{kg}$ on a dry weight basis (Roberfroid et al. 1993), which increases faecal bulk and dry matter.

In a study where eight volunteers were given $15 \mathrm{~g}$ oligofructose/d, Gibson et al. (1995) observed an increased stool weight corresponding to $1.5-2 \mathrm{~g}$ faecal weight increase per gram oligofructose ingested. Intestinal transit time was not affected. E Den Hond, B Geypens and Y Ghoos (unpublished results) confirmed the impact of NDO on bowel habit with long-chain inulin in slightly constipated volunteers. They demonstrated a significant increase in stool frequency, and hence a relief of constipation, in this group of volunteers. They confirmed the $1.5-2 \mathrm{~g}$ stool weight increase per gram NDO consumed. Together, these effects result in stimulation of regular bowel habit. In terms of public health, this translates into relief of constipation, which is particularly frequent in the elderly and in young children.

Consensus. There is consistent evidence of an effect of NDO on bowel habit, which results in a typical faecal bulking effect of $1.5-2 \mathrm{~g}$ increase per gram NDO ingested, and in a normalization of stool frequency (aiming at daily defecation).

\section{Production of short-chain fatty acids}

State of the art. The anaerobic microflora in the colon convert carbohydrates to short-chain fatty acids. As different carbohydrates appear to stimulate growth and metabolic activity of different populations of the colonic ecosystem to different extents, their fermentation results in the formation of different proportions of acetate, propionate and butyrate. In vitro fermentations with human faecal or rat caecal microflora indicate that inulin-type fructans typically increase the production of acetate and of butyrate (indicating that populations other than the bifidobacteria also benefit, as bifidobacteria do not produce butyrate), whereas galacto-oligosaccharides increase the production of acetate and propionate, and xylo-oligosaccharides that of acetate only (Campbell et al. 1997; Djouzi \& Andrieux, 1997).

\section{Prebiotic effect}

State of the art. At the start of the ENDO project, the concept of a prebiotic was introduced into nutritional 
science (Gibson \& Roberfroid, 1995). A prebiotic was defined as a non-digestible food ingredient that beneficially affects the host by selectively stimulating the growth and/or activity of one or a limited number of bacteria in the colon, thus improving host health.

The only prebiotic effect that has been fully demonstrated is the selective stimulation of the growth of bifidobacteria in complex microbial communities that exist in the colon. Bifidobacteria are generally classified as health-promoting and, along with lactobacilli, are used as probiotics. No harmful effect related to their oral intake has been reported, but work is required to demonstrate specific health effects. Hitherto, the only NDO for which such a demonstration has been made convincingly, both in vitro, and most importantly in human subjects in vivo, appear to be the inulin-type fructans inulin and oligofructose (Roberfroid et al. 1998; see Table 3). These prebiotic ingredients are regarded as potentially beneficial for health because they lead to an increase in barrier function and reduction in risk of intestinal infections.

ENDO contribution. The main contribution of the ENDO project to the prebiotic concept concerned the development of methodological approaches to study such effects. The prebiotic effect of NDO has been studied by means of both in vitro and human in vivo experiments.

\section{Prebiotic effect: in vitro experiments}

These experiments concern fermentations carried out in small bioreactors inoculated with pure bacterial strains, reconstituted mixtures or faecal slurries. Variables such as temperature, $\mathrm{pH}$ and nutrient composition are carefully controlled. This technique allows study of the influence of NDO on the bacterial composition of mixed bacterial faecal slurries as well as the fermentation of NDO by pure bacterial cultures.

The different compartments of the colon can be simulated with continuous culture experiments with (sequences of) chemostats (Macfarlane et al. 1998). One limitation of this type of experiment is that metabolites are not withdrawn from the environment as they are in the colon. The accumulation of these products affects the equilibrium of many ongoing biochemical processes (inhibition). It is not possible to quantify the influence of the artificial environment of a bioreactor. Nevertheless, the relative comparisons that can be studied are considered important tools in prebiotic research, as they allow the demonstration (qualitatively) of certain mechanisms, leading to the formulation of hypotheses that can be tested by well-designed human feeding studies.

In the ENDO project, an in vitro gnotoxenic (bacterial flora with known composition) fermentation chemostat proved to be a suitable model for studying bacterial interactions (barrier effect or colonization resistance; D Newton, J Cummings,

Table 2. Overview of the evolution of in vitro fermentation experiments with non-digestible oligosaccharides (NDO), leading to the assumption that NDO are prebiotic compounds

\begin{tabular}{|c|c|c|c|}
\hline Reference & Model & Substrate & Effect \\
\hline Wada (1990) & $\begin{array}{l}\text { Test-tube; pure cultures } \\
\text { (various) }\end{array}$ & Inulin, oligofructose, glucose & $\begin{array}{l}\mathrm{pH} \text { measurements gave a first indication of the } \\
\text { selective promotion of Bifidobacteria }\end{array}$ \\
\hline Wang \& Gibson (1993) & $\begin{array}{l}\text { Batch; faecal slurry as } \\
\text { inoculum }\end{array}$ & $\begin{array}{l}\text { Glucose, galactose, arabinose, } \\
\text { fructose, lactose, sucrose, } \\
\text { cellobiose, lactulose, } \\
\text { oligofructose, inulin, starch, } \\
\text { pectin, arabinogalactan, } \\
\text { sorbitol, lactitol, maltitol, } \\
\text { polydextrose }\end{array}$ & $\begin{array}{l}\text { Pronounced selective increase in Bifidobacteria } \\
\text { demonstrated } \\
\text { Monitoring of SCFA production revealed high } \\
\text { acetate (and lactate) production with } \\
\text { oligofructose }\end{array}$ \\
\hline Gibson \& Wang (1994a) & $\begin{array}{l}\text { Batch; pure culture } \\
\text { (Bifidobacteria, E. coli, } \\
\text { C. perfringens, } \\
\text { Bacteroides) }\end{array}$ & $\begin{array}{l}\text { Inulin, oligofructose, branched } \\
\text { oligofructose, glucose }\end{array}$ & $\begin{array}{l}\text { Growth rate of Bifidobacteria on } \\
\text { oligofructose }>\text { inulin }>\text { branched } \\
\text { oligofructose }>\text { glucose. In the non- } \\
\text { Bifidobacteria pure cultures, fastest growth } \\
\text { was observed on glucose }\end{array}$ \\
\hline Gibson \&Wang (1994b) & $\begin{array}{l}\text { Batch; diffusion } \\
\text { chemostat. Single } \\
\text { chemostat, inoculated } \\
\text { with pure cultures }\end{array}$ & Oligofructose & $\begin{array}{l}\text { Demonstration of inhibitory effects of } \\
\text { Bifidobacteria on the growth of other colonic } \\
\text { bacteria, possibly explaining enhanced } \\
\text { bifidogenic effect }\end{array}$ \\
\hline McBain \& MacFarlane (1997) & $\begin{array}{l}\text { Three-stage chemostat; } \\
\text { methanogen-free } \\
\text { faecal slurry as } \\
\text { inoculum }\end{array}$ & Inulin & $\begin{array}{l}\text { Selective increase of Bifidobacteria } \\
\text { Decrease of Clostridia }\end{array}$ \\
\hline Hopkins et al. (1998) & $\begin{array}{l}\text { Batch; pure culture with } \\
\text { Bifidobacterium spp. }\end{array}$ & $\begin{array}{l}\text { Xylo-OS, galacto-OS, } \\
\text { soyabean OS, inulin, } \\
\text { pyrodextrin, oligofructose }\end{array}$ & $\begin{array}{l}\text { Measurement of maximal specific growth rate } \\
(\mu \text { max) revealed significant interspecies } \\
\text { differences depending on growth substrates }\end{array}$ \\
\hline Newton et al.* & $\begin{array}{l}\text { Chemostat; defined } \\
\text { population of fifteen } \\
\text { pure cultures } \\
\text { representing the most } \\
\text { abundant intestinal } \\
\text { bacteria }\end{array}$ & $\begin{array}{l}\text { A mixture of inulin, pectin, xylan, } \\
\text { arabinogalactan and starch }\end{array}$ & $\begin{array}{l}\text { Validation of the model allowing study of } \\
\text { bacterial interactions (e.g. colonization } \\
\text { resistance) }\end{array}$ \\
\hline
\end{tabular}


S Macfarlane and G Macfarlane unpublished results). Table 2 summarizes the in vitro microflora experiments.

Consensus. The results obtained from in vitro fermentation experiments (batch and continuous cultures inoculated either with faecal slurries or pure cultures) are important in prebiotic investigations, particularly when integrated with information from human in vivo studies. Combination of these data provides valuable insight into the mechanisms of prebiotic action. In vitro models alone cannot be considered adequate for study of the complex ecosystem of the colon.

Pure culture results cannot be used to show a prebiotic effect. Indeed, in such conditions most NDO are fermented by miscellaneous species and strains, but these findings do not preclude selective stimulation among complex mixtures of micro-organisms. A simplified chemostat model of the colonic microbiota (with a known population of the fifteen most abundant intestinal bacteria) shows exceptional promise for elucidating the underlying principles associated with bacterial cell-cell interactions (barrier effect or colonization resistance).

As a result of the discussion of the available scientific data, the authors propose the following definition: "A prebiotic effect is a food-induced increase in numbers and/or activity predominantly of bifidobacteria and lactic acid bacteria in the human intestine'. This definition is an adapted version of that of Gibson \& Roberfroid (1995) and implies that besides bifidobacteria and lactic acid bacteria, some ('selectivity') other bacteria may be stimulated. However, the definition incorporates the bifidobacteria and the lactic acid bacteria because they are considered good biomarkers of a well-balanced intestinal flora. The health aspect is omitted from the definition, because to date no information is available which could support such a statement.

\section{Prebiotic effect: in vivo human nutrition studies}

State of the art. Table 3 lists published and scientifically sound (criteria are faecal sample pretreatment, confirmation of the identity of counted colonies, control of dietary intake) studies investigating the bifidogenic properties of various types of NDO.

Table 3. Overview of human nutrition studies investigating the prebiotic (bifidogenic) properties of different non-digestible oligosaccharides (NDO)

\begin{tabular}{|c|c|c|c|c|c|c|c|}
\hline Reference & $\begin{array}{c}\text { Dose }(\mathrm{g} / \mathrm{d}) \\
\text { Type of NDO }\end{array}$ & $\begin{array}{l}\text { No. volunteers } \\
\text { Age (years) } \\
\text { Supplement } \\
\text { period }\end{array}$ & $\begin{array}{c}\text { Control of } \\
\text { bacteriological } \\
\text { measurement }\end{array}$ & $\begin{array}{l}\text { Remarks } \\
\text { on } \\
\text { protocol }\end{array}$ & $\begin{array}{c}\text { Log } \\
\text { increase in } \\
\text { Bifidobacteria }\end{array}$ & $\begin{array}{c}\text { Statistical } \\
\text { significance }\end{array}$ & Indication of selectivity \\
\hline Bouhnik et al. (1997) & $\begin{array}{l}10 \cdot 0 \\
\text { TOS }\end{array}$ & $\begin{array}{l}8(4 \mathrm{M} / 4 \mathrm{~F}) \\
24-32 \\
21 \mathrm{~d}\end{array}$ & $\begin{array}{l}\text { Selectivity of } \\
\text { medium }\end{array}$ & - & $1 \cdot 1$ & $P<0.05$ & $\begin{array}{l}\text { Bifidobacteria increased } \\
\text { whereas enterobacteria were } \\
\text { not affected }\end{array}$ \\
\hline Gibson et al. (1995) & $\begin{array}{l}15 \\
\text { Inulin }\end{array}$ & $\begin{array}{l}4(\mathrm{M}) \\
20 \\
2 \text { weeks }\end{array}$ & $\begin{array}{l}\text { Microscopy and } \\
\text { fermentation }\end{array}$ & $\begin{array}{l}\text { Fresh } \\
\text { faecal } \\
\text { samples }\end{array}$ & 0.9 & $P<0.001$ & No change in other groups \\
\hline Ito et al. (1993) & $\begin{array}{l}15 \\
\text { TOS }\end{array}$ & $\begin{array}{l}12(\mathrm{M}) \\
27-43 \\
1 \text { week }\end{array}$ & Microscopy & $\begin{array}{l}\text { Fresh } \\
\text { faecal } \\
\text { samples }\end{array}$ & $\begin{array}{l}0.25 \text { (high } \\
\text { initial } \\
\text { counts) }\end{array}$ & $\begin{array}{l}P<0.01 \\
\text { (increase in } \\
\text { lactobacillus } \\
P<0.05 \text { ) }\end{array}$ & $\begin{array}{l}\text { Bacteroides and clostridia } \\
\text { decreased }\end{array}$ \\
\hline Menne \& Guggenbuhl (1997) & $\begin{array}{l}8 \\
\mathrm{~F}_{n} \text {-type } \\
\text { oligofructose }\end{array}$ & $\begin{array}{l}8(5 \mathrm{M} / 3 \mathrm{~F}) \\
20-50 \\
2 \text { weeks }\end{array}$ & Microscopy & $\begin{array}{l}\text { Fresh } \\
\text { faecal } \\
\text { samples }\end{array}$ & 0.9 & $P<0.05^{\star}$ & No change in other groups \\
\hline Mitsuoka et al. (1987) & $\begin{array}{l}8 \\
\text { Oligofructose }\end{array}$ & $\begin{array}{l}23(\mathrm{M}) \\
50-90 \\
2 \text { weeks }\end{array}$ & $\begin{array}{l}\text { Colony type } \\
\text { microscopy }\end{array}$ & - & 0.9 & $P<0.005^{*}$ & $\begin{array}{l}\text { Decrease in enterobacteria; } \\
\text { other measured groups } \\
\text { remained constant }\end{array}$ \\
\hline Rochat et al. $\dagger$ & $\begin{array}{l}8 \\
\text { Oligofructose }\end{array}$ & $\begin{array}{l}38(\mathrm{M}) \\
\text { Adult } \\
2 \text { weeks }\end{array}$ & $\begin{array}{l}\text { Selectivity of } \\
\text { medium }\end{array}$ & $\begin{array}{l}\text { Fresh } \\
\text { faecal } \\
\text { samples }\end{array}$ & 1.35 & $\begin{array}{l}P<0.01 \\
\text { (increase in } \\
\text { lactobacillus } \\
P<0.05 \text { ) }\end{array}$ & $\begin{array}{l}\text { Decrease of clostridia } \\
\text { Others not affected }\end{array}$ \\
\hline Buddington et al. (1996) & $\begin{array}{l}4 \\
\text { Oligofructose }\end{array}$ & $\begin{array}{l}12(6 \mathrm{M} / 6 \mathrm{~F}) \\
20-34 \\
25 \mathrm{~d}\end{array}$ & $\begin{array}{l}\text { Selective media/ } \\
\text { colony type }\end{array}$ & $\begin{array}{l}\text { Fresh } \\
\text { faecal } \\
\text { samples }\end{array}$ & 0.8 & $P<0.03^{*}$ & No distinct evidence \\
\hline
\end{tabular}


Considering this plethora of data on the bifidogenicity of inulin and oligofructose, the authors reached consensus on the conclusion that inulin-type fructans or $\beta(2 \rightarrow 1)$ fructans, independent of chain length, all have significant prebiotic properties. There is no difference in prebiosis between oligofructose obtained by synthesis from sucrose and that obtained by partial enzymic hydrolysis from chicory inulin (Gibson \& Wang, 1994b; Bouhnik et al. 1996a; Buddington et al. 1996).

Partial enzymic hydrolysis of inulin (molecules composed of $\beta(2 \rightarrow 1)$-linked fructose chains with lengths varying between three and sixty monomers attached to a single glucose unit) results in the formation of $\mathrm{GF}_{n}$ and $\mathrm{F}_{n}$-type fructans (where $\mathrm{G}$ is glucose, $\mathrm{F}$ is fructose and $n$ is the number of fructose moieties). Menne \& Guggenbuhl (1997) observed a bifidogenic effect with $\mathrm{F}_{n}$-type fructans that was similar to earlier observations with $\mathrm{GF}_{n}$-type fructans. Roberfroid et al. (1998) concluded from their compilation work that in a large population there seems to be no doseresponse effect of these NDO on the increase in numbers of bifidobacteria, for daily intake doses between 4 and $40 \mathrm{~g} / \mathrm{d}$. This is because the bifidogenic effect is inversely related to the volunteer's initial bifidus count.

In all of these carefully executed experiments, a significant bifidogenic, and hence prebiotic, effect of inulin and/or oligofructose has been observed. Three human studies have been performed with transgalactosylated oligosaccharides (Ito et al. 1993; Bouhnik et al. 1997; Alles et al. 1998b), of which two demonstrated a prebiotic effect and one showed no effect.

The consistently observed prebiotic potential of inulintype fructans may be ascribed to their molecular structure: linear chains composed of mainly $\beta(2 \rightarrow 1)$-linked fructose molecules. The other types of NDO are either branched, and yet less readily accessible for bacterial hydrolysis, or composed of several types of glycosidic bonds, which makes induction of specific enzyme systems to degrade them less efficient.

Consensus. There is now strong evidence, based on observations with over 100 volunteers differing in sex, age, race and dietary habits, showing that $\beta(2 \rightarrow 1)$-type fructans are prebiotic (Roberfroid et al. 1998). Few human feeding studies investigating the bifidogenic potential of galactooligosaccharides seem to indicate that they may have a prebiotic potential. There are preliminary animal studies indicating prebiotic effects of soyabean oligosaccharides. A significant fraction of these compounds is absorbed in the small intestine, and thus becomes unavailable for colonic fermentation. Very little scientific information on xylo-oligosaccharides and pyrodextrins is available.

Perspectives. To perform human prebiosis studies is extremely laborious and time-consuming. In these studies, the classical plate-counting techniques are the bottle-neck. Studies designed to develop and validate quantitative techniques making use of $16 \mathrm{~S}$ rRNA probes to assess the microflora are underway.

Another technique that might prove to be useful is the MIDI system (an acronym of MIcrobial IDentification; a Corporation in Barksdale Professional Center, Newark, DE, USA), which uses cellular fatty acids as bacterial biomarkers. The system is GC-based, and is interfaced to a computer containing libraries for several hundred different bacterial species. The organisms, in pure or mixed cultures, are identified on the basis of their whole-cell fatty acid (as methyl ester) profiles. Reproducible markers have been identified for particular groups of bacteria (e.g. Bacteroides, bifidobacteria, clostridia; D Newton, J Cummings, S Macfarlane and G Macfarlane, unpublished results). These less laborious techniques are promising tools for executing human prebiosis studies on a larger scale (greater number of volunteers, and longer study periods).

\section{Effect of non-digestible oligosaccharides on mineral absorption}

State of the art. There is increasing evidence that NDO improve the bioavailability of minerals. Ohta et al. (1993, 1994, 1995), Delzenne et al. (1995), Scholz-Ahrens et al. (1998) and Lemort \& Roberfroid (1997) published the results of rat studies in which increased $\mathrm{Ca}$ and $\mathrm{Mg}$ absorption following consumption of inulin-type fructans was observed. Baba et al. (1996) formulated the hypothesis that the effects of NDO on $\mathrm{Ca}$ and $\mathrm{Mg}$ absorption occur at the level of the large intestine. This represents a new concept, as it is generally accepted that mineral absorption occurs mainly via the small intestine. Using ovariectomized rats functioning as a model for postmenopausal women, Scholz-Ahrens et al. (1998) observed a dose effect of inulin on increased $\mathrm{Ca}$ absorption and demonstrated that the increased amount of absorbed $\mathrm{Ca}$ was effectively used to increase bone mineral density. This opens the way to considering consumption of inulin to reduce the risk of osteoporosis.

Further, it was observed by Delzenne et al. (1995) in normal rats and by Ohta et al. (1995) in anaemic rats that intake of inulin-type fructans increased the blood $\mathrm{Fe}$ content. Chonan \& Watanaki (1995) reported an increase in $\mathrm{Ca}^{2+}$ absorption in rats that were administered transgalactosylated oligosaccharides. Ellegård et al. (1996), in studies with ileostomized volunteers who were administered inulin and oligofructose, observed that the intake of NDO did not alter the transition of $\mathrm{Ca}^{2+}, \mathrm{Mg}^{2+}, \mathrm{Zn}^{2+}$ and $\mathrm{Fe}^{2+}$ from the ileum into the colon. This suggests that the altered mineral absorption is due to events taking place in the colon.

ENDO contribution. Two human feeding studies were performed during the ENDO project. van Dokkum et al. (1995) optimized a stable-isotope technique, which was applied to healthy young male adults consuming $15 \mathrm{~g}$ inulin, oligofructose or galacto-oligosaccharides/d. The study did not demonstrate an effect of NDO on mineral absorption. When reinvestigating the protocol, it was thought that the sampling period for the inulin studies $(24 \mathrm{~h})$ may have been too short to take into account colonic effects. Noting that all previous rat experiments were carried out with growing animals, a second study was performed with a group of male adolescents. It is thought that the mineral absorption rate is highest during adolescence and that it determines acquired bone mineral density. The colonic part of $\mathrm{Ca}^{2+}$ absorption was included by extending the collection of urine to $36 \mathrm{~h}$ after isotope administration.

Twelve volunteers consumed $15 \mathrm{~g}$ oligofructose/d for 1 week. A significant increase $(+25 \% ; P<0.05)$ in $\mathrm{Ca}^{2+}$ 
Table 4. Overview of human feeding studies investigating the effect on mineral absorption of non-digestible oligosaccharides (NDO) consumption

\begin{tabular}{|c|c|c|c|c|c|}
\hline Reference & $\begin{array}{c}\text { NDO } \\
\text { Dose (g/d) } \\
\text { Intake period (weeks) }\end{array}$ & $\begin{array}{l}\text { No. of male } \\
\text { volunteers } \\
\text { Age (years) }\end{array}$ & Method of measurement & Result & $\begin{array}{c}\text { Statistical } \\
\text { significance }\end{array}$ \\
\hline Coudray et al. (1997) & $\begin{array}{l}\text { Inulin } \\
40 \\
4\end{array}$ & $\begin{array}{l}9 \\
19-24\end{array}$ & Apparent mineral absorption & $\begin{array}{l}\mathrm{Ca}, 58 \% \text { increase (from } 21.3 \text { to } 33.7 \% \text { ) } \\
\mathrm{Mg}, \mathrm{Fe}, \mathrm{Zn} \text {, no effect }\end{array}$ & $P<0.01$ \\
\hline van den Heuvel et al.* & $\begin{array}{l}\text { Oligofructose, } \\
\text { inulin, TOS } \\
15 \\
3\end{array}$ & $\begin{array}{l}12 \\
20-26\end{array}$ & $\begin{array}{l}\text { True mineral absorption } \\
\text { ( } 24 \mathrm{~h} \text { urine collection; may } \\
\text { have been too short) }\end{array}$ & $\begin{array}{l}\text { No altered } \mathrm{Ca} \text { or } \mathrm{Fe} \text { absorption with } \\
\text { any NDO tested }\end{array}$ & - \\
\hline
\end{tabular}

TOS, transgalactosylated oligosaccharides.

${ }^{*}$ EGH van den Heuvel, Th Muys, W van Dokkum and G Schaafsma, unpublished results.

absorption was observed as compared with a placebo (van den Heuvel et al. 1999).

During the execution of the ENDO project, Coudray et al. (1997) observed an increase $(+58 \% ; P<0.01)$ in apparent $\mathrm{Ca}$ absorption in a group of nine adult volunteers who consumed $40 \mathrm{~g}$ inulin/d (Table 4).

Consensus. The stimulation of mineral $\left(\mathrm{Ca}^{2+}, \mathrm{Mg}^{2+}\right.$ and $\mathrm{Fe}^{2+}$ ) absorption by inulin-type fructans and transgalactosylated oligosaccharides has been repeatedly confirmed in rat studies. The use of different models indicates that the increased absorption originates mainly at the level of the large intestine and effectively results in increased bone mineral density. There is promising evidence that the consumption of inulin-type fructans results in increased $\mathrm{Ca}^{2+}$ absorption in human subjects. Two human feeding studies showed a significant effect, whereas in another study no effect was observed, but this may have been due to a suboptimal study design. Results from animal models indicate similar effects for $\mathrm{Mg}^{2+}$ and $\mathrm{Fe}^{2+}$ absorption. There is limited evidence for effects of transgalactosylated oligosaccharides in animal models only. There are no data available indicating comparable effects for other NDO.

\section{Effect of non-digestible oligosaccharides on lipid metabolism}

At the start of the ENDO project it was known that feeding rats on a diet supplemented with inulin-type fructans induces a hypolipidaemic and, more particularly, a hypotriacylglycerolaemic effect (Fiordaliso et al. 1995). It was one of the objectives of the ENDO project to study this effect in more detail and potentially to confirm it in human volunteers.

State of the art. Lowering of serum triacylglycerols in rats has been reported by Hata et al. (1983) and Delzenne et al. (1993) with inulin-type oligosaccharides (100 g/kg dose level) and by Kaneko et al. (1992) with isomaltooligosaccharides. Cholesterol levels were not always reduced; when they were, this was observed only after a prolonged feeding period ( $>12$ weeks).

Yamashita et al. (1984) described a reduction of LDLcholesterol and fasting blood glucose levels in eighteeen non-insulin-dependent diabetic subjects given oligofructose $(8 \mathrm{~g} / \mathrm{d}$ for $14 \mathrm{~d})$. They observed that the reduction was greater in hypercholesterolaemic subjects. No effect on circulating triacylglycerols was seen.

Alles et al. (1998a) repeated the experiment with $15 \mathrm{~g}$ oligofructose/d for $20 \mathrm{~d}$. They observed no effect on fasting circulating lipid variables, nor on fasting glucose levels. A postprandial study was not performed in any of these studies.

A study with healthy but slightly hyperlipidaemic subjects by Davidson et al. (1998) resulted in a regulating effect of inulin $(18 \mathrm{~g} / \mathrm{d})$ on total and LDL-cholesterol levels. However, the experimental protocol was biased by the study food used, which did not allow the observations to be attributed unequivocally to the inulin intake.

Canzi et al. (1995) observed that the intake of inulin $(9 \mathrm{~g} / \mathrm{d})$ resulted in a reduction in serum triacylglycerol and cholesterol levels, whereas Pedersen et al. (1997) observed no effect with inulin $(14 \mathrm{~g} / \mathrm{d})$ in a group of healthy normolipidaemic women. Recently, Williams (1998) performed a human feeding study with fifty-four healthy but slightly hyperlipidaemic volunteers. They were administered $10 \mathrm{~g}$ long-chain inulin/d. There were no effects on cholesterol, but fasting serum triacylglycerols ( $-19 \%$ after 8 weeks) and insulin levels $(-17 \%$ after 4 weeks and $-10 \%$ after 8 weeks) dropped significantly.

ENDO contribution. Studies with isolated hepatocytes showed reduced hepatic lipogenic activity in NDO-fed rats, and led to the observation that the activity of all hepatic lipogenic enzymes was significantly downregulated $(-50 \%)$ in the $\beta(2 \rightarrow 1)$ fructan-fed rats (Kok et al. 1996b). This may be due to modified genetic regulation (gene expression) in the liver. Further research revealed that this might be induced by hormonal changes (inulin, glucagon-like protein of type 1 and glucose-dependent insulinotropic polypeptide; Kok et al. 1998a). It is hypothesized that bacterial metabolites (more particularly propionate) from NDO fermentation are involved (Alamowitch et al. 1993). Further, it was demonstrated by Kok et al. $(1998 b)$ that the increase in postprandial triacyglycerol levels that is induced by a fat-rich (Western-type) diet is decreased $(-50 \%)$ in rats on oligofructose feeding, and that the increase in liver triacylglycerol induced by a high fructose load is suppressed in oligofructose-fed rats (Kok et al. 1996a). 
Controlled feeding studies by van Dokkum et al. (1995) with normolipidaemic healthy volunteers resulted in no effect with $15 \mathrm{~g}$ oligofructose, inulin or transgalactosylated oligosaccharides/d during a period of 3 weeks. The blood lipid variables of these subjects were optimal, and according to recent findings by Williams (1998), the feeding period rather short. It is worthwhile noting that the intake of NDO did not negatively affect the blood lipid variables.

In a second ENDO study by van Vliet (1997) with a group of fifty slightly hyperlipidaemic male volunteers, of whom twenty-five received $15 \mathrm{~g}$ oligofructose/d for 3 weeks, and twenty-five were given control food, no effect on fasting serum lipid variables was observed. From these data, it appears that to elucidate any effect of NDO on the many mechanisms (bile acid metabolism, intestinal flora, liver lipid metabolism, hormone status, which are linked to nutrition status, health condition, age, sex, etc.) that interact with lipid metabolism, the study design is of utmost importance. The studies described in Table 5 cannot be compared directly, as they all differ in some aspects.

Consensus. There is preliminary evidence from animal studies that lipid metabolism is affected by inulin-type fructans. The experimental design for human nutrition studies is critical if effects are to be demonstrated unambiguously. The data available at present are still inconsistent, but indicate that the intake of moderate levels of inulin or oligofructose may affect human lipid metabolism. They are the basis for further ongoing studies investigating other aspects of lipid metabolism (insulin and incretins, obesity, diabetes). There is no indication of an effect on lipid metabolism in human subjects for transgalacto-oligosaccharides or any other type of NDO.

\section{Interaction of non-digestible oligosaccharides with the carcinogenesis process and immunology}

This topic was not part of the ENDO project but available experimental studies were discussed by the authors during the consensus report meeting.

State of the art. Only evidence from animal experiments is available. Reddy et al. (1997) added $100 \mathrm{~g}$ longchain inulin and oligofructose/kg to the diet of rats. After adaptation, the animals were injected with azoxymethane. For both types of fructan, a statistically significant reduction in the numbers of colonic aberrant crypt foci was observed. These preneoplastic lesions are early indicators of future risk of tumour development (Table 6).

Rowland et al. (1998) administered $50 \mathrm{~g}$ long-chain inulin/kg diet to rats following azoxymethane injection

Table 5. Summary of published human nutrition studies (including ENDO project results) of the effect of non-digestible oligosaccharides (NDO) on lipid metabolism

\begin{tabular}{|c|c|c|c|c|c|}
\hline Reference & $\begin{array}{c}\text { NDO } \\
\text { Dose }(\mathrm{g} / \mathrm{d}) \\
\text { Intake period }(\mathrm{d})\end{array}$ & $\begin{array}{l}\text { Number of } \\
\text { volunteers } \\
\text { Type } \\
\text { Age (years) }\end{array}$ & Study design & Fasting serum levels & $\begin{array}{l}\text { Postprandial } \\
\text { measurements }\end{array}$ \\
\hline Canzi et al. (1995) & $\begin{array}{l}\text { Inulin } \\
9 \\
28\end{array}$ & $\begin{array}{l}12 \mathrm{M} \\
\text { Normolipidaemic } \\
23 \text { (SD 0.5) }\end{array}$ & $\begin{array}{l}\text { Run-in (placebo) of } \\
4 \text { weeks; } 4 \text { weeks inulin- } \\
\text { containing study food }\end{array}$ & $\begin{array}{l}\text { ITotal-C } \\
\text { ILDL-C } \\
=\text { HDL-C } \\
\text { ITG } \\
\text { NM Glucose }\end{array}$ & NM \\
\hline Pedersen et al. (1997) & $\begin{array}{l}\text { Inulin } \\
14 \\
28\end{array}$ & $\begin{array}{l}64 \mathrm{~F} \\
\text { Normolipidaemic } \\
\text { 'Young' }\end{array}$ & $\begin{array}{l}\text { Cross-over study without } \\
\text { washout period }\end{array}$ & $\begin{array}{l}\text { Reduced LDL:HDL ratio; } \\
\text { no effect on Total-C, TG } \\
\text { or glucose }\end{array}$ & NM \\
\hline Davidson et al. (1998) & $\begin{array}{l}\text { Inulin } \\
18 \\
42\end{array}$ & $\begin{array}{l}24(12 \mathrm{M} / 13 \mathrm{~F}, \text { Caucasian) } \\
\text { Hyperlipidaemic } \\
60 \text { (SD 5) }\end{array}$ & $\begin{array}{l}\text { Double-blind cross-over } \\
\text { with 6-week washout period } \\
\text { Volunteers on low-fat diet } \\
\text { (fat }<30 \% \text { of energy) }\end{array}$ & $\begin{array}{l}\text { \Total-C } \\
\text { \LDL-C } \\
=\text { HDL-C } \\
=\text { TG } \\
\text { NM Glucose }\end{array}$ & NM \\
\hline van Vliet (1997) & $\begin{array}{l}\text { Oligofructose } \\
15 \\
21\end{array}$ & $\begin{array}{l}50 \mathrm{M} \\
\text { Hyperlipidaemic } \\
\text { (TG } 2.5 \text { (SD 0.9) } \mathrm{mmol} / \mathrm{l}) \\
50(\mathrm{SD} 7)\end{array}$ & $\begin{array}{l}\text { Parallel ( } 25 \text { subjects on } \\
\text { study food and } 25 \text { on } \\
\text { placebo) } \\
\text { No controlled diet }\end{array}$ & No effect & $\begin{array}{l}\text { Glucosaemia and } \\
\text { insulinaemia: no } \\
\text { difference with } \\
\text { placebo detected }\end{array}$ \\
\hline Williams (1998) & $\begin{array}{l}\text { Long-chain } \\
\text { inulin } \\
10 \\
56\end{array}$ & $\begin{array}{l}54(\mathrm{M} / \mathrm{F}) \\
\text { Hyperlipidaemic } \\
\text { (TG } 1.2-3 \mathrm{mmol} / \mathrm{l}, \\
\text { TC } 5.5-8 \mathrm{mmol} / \mathrm{)}) \\
35-70\end{array}$ & $\begin{array}{l}\text { Double-blind randomized } \\
\text { placebo-controlled }\end{array}$ & $\begin{array}{l}=\text { Total-C } \\
=\mathrm{LDL}-\mathrm{C} \\
=\mathrm{HDL}-\mathrm{C} \\
\downarrow \mathrm{TG}\end{array}$ & $\begin{array}{l}=\text { Glucosaemia } \\
\downarrow \text { fasting insulin } \\
\text { levels during inulin } \\
\text { intake }\end{array}$ \\
\hline
\end{tabular}

C, cholesterol; Total-C, LDL-C+HDL-C; TG, triacylglycerols; TC, total cholesterol; NM, not monitored; M, Male; F, Female; $\downarrow$, reduction; =, no change; NIDD, noninsulin-dependent diabetic. 
Table 6. Overview of animal studies demonstrating the chemopreventive action of non-digestible oligosaccharides (NDO) in colon cancer

\begin{tabular}{|c|c|c|c|c|}
\hline Reference & $\begin{array}{l}\text { Type of NDO } \\
\text { Dose }\end{array}$ & $\begin{array}{l}\text { Animal } \\
\text { Numbers }\end{array}$ & Protocol & Observation \\
\hline Gallaher et al. (1996) & $\begin{array}{l}\text { OF }(20 \mathrm{~g} / \mathrm{kg} \text { diet }) \\
\text { Bifidobacterium spp. }\left(10^{8}\right) \\
\text { OF+bifidobacteria }\end{array}$ & $\begin{array}{l}\text { Rat } \\
15 / \text { group }\end{array}$ & $\begin{array}{l}\text { DMH injections before administering } \\
\text { study food }\end{array}$ & $\begin{array}{l}\text { Decrease in ACF with } \\
\text { OF }+ \text { Bif }>\text { OF }>\text { Bif } \\
\text { (synbiotic effect) }\end{array}$ \\
\hline Reddy et al. (1997) & $\begin{array}{l}\text { Long-chain inulin } \\
\text { OF } \\
100 \mathrm{~g} / \mathrm{kg} \text { diet }\end{array}$ & $\begin{array}{l}\text { Rat } \\
12 / \text { group }\end{array}$ & $\begin{array}{l}\text { NDO feeding started } 2 \text { weeks before } \\
\text { AOM injections. Counting of ACF } \\
8 \text { weeks after last AOM treatment } \\
\text { (impact on initiation and on } \\
\text { propagation phase) }\end{array}$ & $\begin{array}{l}\text { Inulin, }-35 \% \mathrm{ACF}^{\star *} \\
\text { OF, } \\
-24 \% \mathrm{ACF}^{\star}\end{array}$ \\
\hline Taper et al. (1997) & $\begin{array}{l}\text { OF, inulin, pectin } \\
150 \mathrm{~g} / \mathrm{kg} \text { diet }\end{array}$ & $\begin{array}{l}\text { Mouse } \\
9-12 / \text { group }\end{array}$ & $\begin{array}{l}\text { Tumour cell lines (EMT6 and TLT) } \\
\text { implanted in the thigh }\end{array}$ & $\begin{array}{l}\text { Mean tumour surface } \\
\text { increase as a measure } \\
\text { for growth was } \\
\text { decreased }\end{array}$ \\
\hline Pierre et al. (1997) & $\begin{array}{l}\text { OF } \\
58 \mathrm{~g} / \mathrm{kg} \text { diet }\end{array}$ & $\begin{array}{l}\text { Min mouse } \\
5 / \text { group }\end{array}$ & $\begin{array}{l}\text { Min mice spontaneously develop } \\
\text { intestinal tumors (mainly in the small } \\
\text { intestine) }\end{array}$ & $\begin{array}{l}\text { Fewer tumours in the } \\
\text { small intestine }\left(^{* *}\right) \text { and } \\
\text { in the colon }\left({ }^{* *}\right) ; \\
\text { stimulation of GALT }\left(^{*}\right)\end{array}$ \\
\hline
\end{tabular}

ACF, total colonic aberrant crypt foci; AOM, azoxymethane; DMH, 1,2-dimethylhydrazine; GALT, gut-associated lymphoid tissue; OF, oligofructose; Bif, bifidobacteria. ${ }^{*} P<0.05 ;{ }^{* *} P<0.01 ;{ }^{* \star} P<0.001$

(post-initiation experiment). They observed a significant reduction in the numbers of colonic aberrant crypt foci, and an inhibition by inulin of the propagation phase of the carcinogen. A comparable effect was induced on administration of bifidobacteria. When long-chain inulin and bifidobacteria were administered simultaneously, a synergistic reduction of the numbers of aberrant crypt foci was obtained. Gallaher et al. (1996) observed a comparable synbiotic effect with oligofructose and bifidobacteria.

Taper et al. (1997) fed a diet containing $150 \mathrm{~g}$ oligofructose or inulin $/ \mathrm{kg}$ to mice bearing intramuscularly implanted tumour cells from two lines (liver tumour cells, TLT; and a mammary carcinoma cell line, MT6) and demonstrated that growth of these tumours was significantly reduced compared with placebo. The same tumour cell lines injected into the peritoneum of mice develop into ascitic tumours. The mean survival time of ascitic tumour-bearing mice which were fed with either inulin or oligofructose was significantly increased compared with placebo-fed mice (Taper et al. 1998).

Pierre et al. (1997) observed a significant reduction in the numbers of spontaneously developing tumours (mainly in the small intestine) in Min-mice associated with oral intake of oligofructose $(58 \mathrm{~g} / \mathrm{kg}$ diet $)$. They reported that the intestinal immune system of the mice was stimulated.

Consensus. The available data, based on research with inulin-type fructans and originating from various types of animal models, consistently demonstrate a reduced risk in experimentally induced carcinogenesis processes. It was thought that these data are sufficient to claim preliminary evidence for interaction of NDO with colon carcinogenesis in experimental animals. The data therefore support the investment for performing human nutrition studies.

\section{Conclusion}

The present compilation of research data (Table 7) emphasizes that NDO, which are present in a Western-type diet in only small quantities, have potential for improving health.

At present there is convincing evidence that: (1) NDO positively affect the composition and metabolic activity of the intestinal microflora (prebiosis); (2) NDO consumption stimulates bowel habit; (3) a daily moderate supplement of NDO stimulates mineral (especially $\mathrm{Ca}$ and $\mathrm{Mg}$ ) absorption, and thus has the potential to prevent or postpone osteoporosis.

Table 7. Consensus on the different functional food effects of non-digestible oligosaccharides in decreasing order of established evidence in human studies

\begin{tabular}{ll}
\hline Effect & Evidence (in human subjects) \\
\hline Prebiotic and interaction with intestinal flora & Strong \\
Regulation of bowel habit, stool bulking, and increase of stool frequency & Strong \\
Increased mineral absorption & Promising \\
Impact on lipid metabolism & Preliminary, data still inconsistent \\
Colon cancer & No human data available \\
& (experimental animals, preliminary) \\
\hline
\end{tabular}


Insufficient evidence is available from human studies to state that NDO systematically improve blood lipid variables. However, ongoing studies may produce more definitive statements.

Promising observations in animal models concerning chemoprevention and retardation of tumour growth in peripheral tissues have been published. This topic deserves more in-depth research and human studies are required.

\section{Acknowledgements}

The ENDO project was fully supported by the European Commission, and more particularly by DGXII (AIRIICT94-1095).

\section{References}

Alamowitch C, Slama G \& Bornet F (1993) Effects of products of dietary fiber fermentation, short-chain fatty acids, on sugar and lipid metabolism. Journées Annuels de Diabetologie, HotelDieu, 245-259.

Alles MS, de Roos NM, Bakx JC, van de Lisdonk E \& Hautvast JGA (1998a) Consumption of fructo-oligosaccharides does not affect blood glucose and serum lipids in non-insulin dependent diabetic subjects. American Journal of Clinical Nutrition (In the Press).

Alles MS, Hartemink R, Meyboom S, Harryvan JK, van Laere KMJ, Nagengast FM \& Hautvast JGAJ (1998b) Effect of transgalacto-oligosaccharides on composition and activity of the intestinal flora. American Journal of Clinical Nutrition (In the Press).

Ammeraal RN, Delgado GA, Tenbarge FL \& Friedman RB (1991) High-performance anion-exchange chromatography with pulsed amperometric detection of linear and branched glucose oligosaccharides. Carbohydrate Research 215, 179-192.

Baba S, Ohta A, Ohtsuki M, Takizawa T, Adachi T \& Hara H (1996) Fructooligosaccharides stimulate the absorption of magnesium from the hindgut in rats. Nutrition Research 16, 657666.

Bouhnik Y, Flourié B, Andrieux C, Bisetti N, Briet F \& Rambaud JC (1996a) Effects of Bifidobacterium sp fermented milk ingestion with or without inulin on colonic bifidobacteria and enzymatic activities in healthy humans. European Journal of Clinical Nutrition 50, 269-273.

Bouhnik Y, Flourié B, D’Agay-bensour L, Pochart P, Gramet G, Durand M \& Rambaud JC (1997) Administration of transgalacto-oligosaccharides increases fecal bifidobacteria and modifies colonic fermentation metabolism in healthy humans. Journal of Nutrition 127, 444-448.

Bouhnik Y, Flourié B, Riottot M, Bisetti N, Gailing M, Guibert A, Bornet FR \& Rambaud J (1996b) Effects of fructo-oligosaccharides ingestion on fecal bifidobacteria and selected metabolic indexes of colon carcinogenesis in healthy humans. Nutrition and Cancer 26, 21-29.

Buddington RK, Williams CH, Chen S \& Witherly SA (1996) Dietary supplement of neosugar alters the fecal flora and decreases activities of some reductive enzymes in human subjects. American Journal of Clinical Nutrition 63, 709-716.

Campbell JM, Fahey GCJ \& Wolf BW (1997) Selected indigestible oligosaccharides affect large bowel mass, cecal and fecal shortchain fatty acids, $\mathrm{pH}$ and microflora in rats. Journal of Nutrition 127, 130-136.

Canzi E, Brighenti FB, Casiraghi MC, Del Puppo E \& Ferrari A (1995) Prolonged consumption of inulin in ready-to-eat breakfast: effect on intestinal ecosystem, bowel habits and lipid metabolism. In COST 92, Workshop. Dietary Fiber and
Fermentation in the Colon, Helsinki, pp. 280-284. Luxembourg: Office for Official Publications of the European Communities.

Cherbut C, Desravannes S, Schnee M, Rival M, Galmiche J \& Delortlaval J (1994) Involvement of small intestinal motility in blood glucose response to dietary fibre in man. British Journal of Nutrition 71, 675-685.

Chonan O \& Watanuki M (1995) Effect of galactooligosaccharides on calcium absorption in rats. Journal of Nutritional Science and Vitaminology 41, 95-104 .

Clydesdale FM (1997) A proposal for the establishment of scientific criteria for health claims for functional foods. Nutrition Reviews 55, 413-423.

Coudray C, Bellanger J, Castiglia-Delavaud C, Rémésy C, Vermorel M \& Rayssiguier Y (1997) Effect of soluble or partly soluble dietary fibres supplementation on absorption and balance of calcium, magnesium, iron and zinc in healthy young men. European Journal of Clinical Nutrition 51, 375-380.

Cummings JH, Roberfroid MB, Andersson H, Barth CA, FerroLuzzi A, Ghoos Y, Gibney MJ, Hermonsen K, James WPT, Korver O, Lairon D, Pascal G \& Voragen AGS (1997) A new look at dietary carbohydrate: chemistry, physiology and health. European Journal of Clinical Nutrition 51, 417-423.

Davidson MH, Maki KC, Synecki C, Torri SA \& Drennan KB (1998) Evaluation of the influence of dietary inulin on serum lipids in adults with hypercholesterolemia. Nutrition Research 18, 503-517.

Delzenne N, Aertssens J, Verplaetse N, Roccaro M \& Roberfroid M (1995) Effect of fermentable fructo-oligosaccharides on energy and nutrients absorption in the rat. Life Science 57, 1579-1587.

Delzenne NM, Kok N, Fiordaliso MF, Deboyser DM, Goethals FM \& Roberfroid MB (1993) Dietary fructooligosaccharides modify lipid metabolism. American Journal of Clinical Nutrition 57, Suppl. 5, S820.

Djouzi Z \& Andrieux C (1997) Compared effects of three oligosaccharides on metabolism of intestinal microflora in rats inoculated with a human faecal flora. British Journal of Nutrition 78, 313-324.

Ellegård L, Andersson H \& Bosaeus I (1996) Inulin and oligofructose do not influence the absorption of cholesterol, and the excretion of cholesterol, $\mathrm{Fe}, \mathrm{Ca}, \mathrm{Mg}$ and bile acids but increase energy excretion in man. A blinded controlled cross-over study in ileostomy subjects. European Journal of Clinical Nutrition 51, 1-5.

Englyst HN, Quigley ME \& Hudson GJ (1994) Determination of dietary fibre as non-starch polysaccharides with gas-liquid chromatographic, high-performance liquid chromatographic or spectrophotometric measurement of constituent sugars. Analyst 119, 1497-1509.

Fiordaliso M, Kok N, Desager J, Goethals F, Deboyser D, Roberfroid M \& Delzenne N (1995) Dietary oligofructose lowers triglycerides, phospholipids and cholesterol in serum and very low density lipoproteins of rats. Lipids 30, 163-167.

Gallaher DD, Stallings WH, Blessing LL, Busta FF \& Brady LJ (1996) Probiotics, cecal microflora, and aberrant crypts in the rat colon 1-4. Journal of Nutrition 126, 1362-1371.

Gibson GR, Beatty ER, Wang X \& Cummings JH (1995) Selective stimulation of bifidobacteria in the human colon by oligofructose and inulin. Gastroenterology 108, 975-982.

Gibson GR \& Roberfroid MB (1995) Dietary modulation of the human colonic microbiota - Introducing the concept of prebiotics. Journal of Nutrition 125, 1401-1412.

Gibson GR \& Wang X (1994a) Bifidogenic properties of different types of fructose-containing oligosaccharides. Food Microbiology 11, 491-498.

Gibson GR \& Wang X (1994b) Enrichment of bifidobacteria from 
human gut contents by oligofructose using continuous culture. FEMS Microbiology Ecology 118, 121-128.

Hata Y, Hara T, Oikawa T, Yamamoto M, Hirose N, Nagashima T, Torihama N, Nakajima K, Watanabe A \& Yamashita M (1983) The effect of fructo-oligosaccharides $\left(\mathrm{Neosugar}^{\circledR}\right)$ on lipidemia. Geriatric Medicine 21, 156-167.

Hoebregs H (1997) Fructans in foods and food products, ionexchange chromatographic method: collaborative study. Journal of AOAC International 80, 1029-1037.

Hopkins MJ, Cummings JH \& Macfarlane GT (1998) Inter-species differences in maximum specific growth rates and cell yields of bifidobacteria cultured on oligosaccharides and other simple carbohydrate sources. Journal of Applied Bacteriology 85, 381386.

Ito M, Kimura M, Deguchi Y, Miyamori-Watabe A, Yajima T \& Kan T (1993) Effects of transgalactosylated disaccharides on the human intestinal microflora and their metabolism. Journal of Nutritional Science and Vitaminology 39, 279-288.

Kaneko T, Kohmoto T, Kikuchi H, Fukui F, Shiota M, Yatake T, Takaku H \& Iino H (1992) Digestibility of isomaltooligosaccharides by rats and effects on serum lipids. Nippon Nogei Kagaku Kaishi 66, 1211-1220.

Kleessen B, Sykura B, Zunft HJ \& Blaut M (1997) Effects of inulin and lactose on fecal microflora, microbial activity, and bowel habit in elderly constipated persons. American Journal of Clinical Nutrition 65, 1397-1402.

Knudsen KEB \& Hessov I (1995) Recovery of inulin from Jerusalem artichoke (Helianthus tuberosus L.) in the small intestine of man. British Journal of Nutrition 74, 101-113.

Kok N, Morgan LM, Williams CM, Roberfroid MB, Thissen J-P \& Delzenne NM (1998a) Insulin, glucagon-like peptide 1, glucose-dependent insulinotropic polypeptide and insulinlike growth factor I as putative mediators of the hypolipidemic effect of oligofructose in rats. Journal of Nutrition 128, 10991103.

Kok N, Roberfroid M \& Delzenne N (1996a) Dietary oligofructose modifies the impact of fructose on hepatic triacylglycerol metabolism. Metabolism 45, 1547-1550.

Kok N, Roberfroid M, Robert A \& Delzenne N (1996b) Involvement of lipogenesis in the lower VLDL secretion induced by oligofructose in rats. British Journal of Nutrition 76, 881-890.

Kok NN, Taper HS \& Delzenne NM (1998b) Oligofructose modulates lipid metabolism alterations induced by a fat-rich diet in rats. Journal of Applied Toxicology 18, 47-53.

Lemort C \& Roberfroid M (1997) Effect of chicory fructooligosaccharides on Ca balance. NDO: Healthy Food for the Colon. Symposium LUW, 4-5 December 1997, p. 163. Wageningen: Wageningen University.

McBain A \& Macfarlane G (1997) Investigations of bifidobacterial ecology and oligosaccharide metabolism in a three-stage compound continuous culture system. Scandinavian Journal of Gastroenterology 222, Suppl., 32-40.

Macfarlane G, Macfarlane S \& Gibson GR (1998) Validation of a three-stage compound continuous culture system for investigating the effect of retention time on the ecology and metabolism of bacteria in the human gut. Microbial Ecology 35, 180-187.

Menne E \& Guggenbuhl N (1997) Prebiotic effect of the (fructosyl-1-fructose) Fm-type inulin hydrolysate in humans. NDO: Healthy Food for the Colon. Symposium LUW, 4-5 December 1997, p. 164. Wageningen: Wageningen University.

Mitsuoka T, Hidaka H \& Eida T (1987) Effect of fructooligosaccharides on intestinal microflora. Die Nahrung 31, 426-436.

Ohta A, Ohtsuki M, Baba S, Takizawa T, Adachi T \& Kimura S (1995) Effects of fructooligosaccharides on the absorption of iron, calcium, and magnesium in iron deficient anemic rats. Journal of Nutritional Science and Vitaminology 41, 281-291.

Ohta A, Ohtsuki M, Takizawa T, Inaba H, Adachi T \& Kimura S (1994) Effects of fructo-oligosaccharides on the absorption of magnesium and calcium by cecectomised rats. International Journal of Vitaminology and Nutrition Research 64, 316-323.

Ohta A, Osakabe N, Yamada K, Saito Y \& Hidaka H (1993) Effects of fructooligosaccharides and other saccharides on calcium, magnesium, and phosphorus absorption in rats. Nippon Eiyo, Shokuryo Gakkaishi 46, 123-129.

Pedersen AA, Sandstrom B \& van Amelsvoort JMM (1997) The effect of ingestion of inulin on blood lipids and gastrointestinal symptoms in healthy females. British Journal of Nutrition 78, 215-222.

Pierre F, Perrin P, Champ M, Bornet F, Meflah K \& Menanteau J (1997) Short-chain fructo-oligosaccharides reduce the occurrence of colon tumors and develop gut-associated lymphoid tissue in min mice. Cancer Research 57, 225-228.

Quemener B, Thibault J \& Coussement P (1994) Determination of inulin and oligofructose in food products, and integration in the AOAC method for measurement of total dietary fibre. Food Science and Technology 27, 125-132.

Reddy DS, Hamid R \& Rao CV (1997) Effect of dietary oligofructose and inulin on colonic preneoplastic aberrant crypt foci inhibition. Carcinogenesis 18, 1371-1374.

Roberfroid M, Gibson GR \& Delzenne N (1993) Biochemistry of oligofructose, a non-digestible fructooligosaccharide: an approach to estimate its caloric value. Nutrition Reviews 51, 137-146.

Roberfroid MB, Van Loo J \& Gibson GR (1998) The bifidogenic nature of chicory inulin and its hydrolysis products. Journal of Nutrition 128, 11-19.

Rowland IR, Rumney CJ, Coutts JT \& Lievense L (1998) Effect of Bifidobacterium longum and inulin on gut bacterial metabolism and carcinogen induced aberrant crypt foci in rats. Carcinogenesis 2, 281-285.

Scholz-Ahrens K, Van Loo J \& Schrezenmeir J (1998) Oligofructose stimuliert die Femurmineralisation in Abhängigkeit von der Calciumzufuhr bei der ovariektomisierten Ratte (The increase in bone mineralization in the ovariectomized rat by oligofructose also depends on Ca supplementation). Zeitschrift für Ernährungswissenschaft 37, 123-124.

Taper H, Delzenne N \& Roberfroid MB (1997) Growth inhibition of transplantable mouse tumors by non digestible carbohydrates. International Journal of Cancer 71, 1109-1112.

Taper HS, Lemort C \& Roberfroid MB (1998) Inhibitory effect of dietary inulin and oligofructose on the growth of transplantable mouse tumor. Anticancer Research (In the Press).

van den Heuvel EGH, Muys Th, van Dokkum W \& Schaafsma G (1999) Oligofructose stimulates calcium absorption in adolescents. American Journal of Clinical Nutrition (In the Press).

van den Heuvel E, Schaafsma G, Muys T \& van Dokkum W (1998) Non-digestible oligosaccharides do not interfere with calcium and non-heme iron absorption in young healthy men. American Journal of Clinical Nutrition 67, 445-452.

van Dokkum W, van den Heuvel EGHM, Havenaar R, Srikumar TS, van Aken P \& Wezendonk B (1995) The effect of non digestible oligosaccharides (NDO) on human physiology. Report TNO. Zeist: TNO.

Van Loo J, Coussement P, De Leenheer L, Hoebregs H \& Smits G (1995) On the presence of inulin and oligofructose as natural ingredients in the Western diet. Critical Reviews in Food Science and Nutrition 35, 525-552.

van Vliet T (1997) A double blind placebo controlled, parallel trial on the effect of oligofructose intake on serum lipids in male volunteers. Report TNO V 97.874. Zeist: TNO.

Wada K (1990) In vitro fermentability of oligofructose and inulin by 
some species of human intestinal flora. Report prepared for ORAFTI, Tienen, Belgium, available on request from J Van Loo. Wang X \& Gibson GR (1993) Effects of the in vitro fermentation of oligofructose and inulin by bacteria growing in the human large intestine. Journal of Applied Bacteriology 75, 373-380.
Williams CM (1998) Effects of inulin on blood lipids in humans. Journal of Nutrition (In the Press).

Yamashita K, Kawai K \& Itakura M (1984) Effects of fructooligosaccharides on blood glucose and serum lipids in diabetic subjects. Nutrition Research 4, 961-966. 